\title{
Effect of gypsum application rate and leaching regime on wheat growth in a highly acidic subsoil
}

\author{
C.D.A. Mc Lay and G.S.P. Ritchie \\ Department of Soil Science and Plant Nutrition, School of Agriculture, University of Western Australia, \\ Nedlands, WA 6009, USA
}

\begin{abstract}
A glasshouse experiment was conducted to investigate gypsum application and leaching on the amelioration of an aluminium (Al) toxic subsoil for wheat growth. Treatments included different rates of gypsum application and amount of leaching prior to wheat being grown. Wheat shoot growth increased when gypsum was applied in both the presence and absence of leaching, but growth was higher with leaching. Gypsum application led to a decrease in toxic Al as a result of a higher jonic strength and activity of $\mathrm{AlSO}_{4}^{+}$ion pairs in the soil solution, and increased Al leached from the soil. Root growth may not be a good bioassay for predicting wheat shoot responses 10 gypsum applications on acidic subsoils.
\end{abstract}

\section{Introduction}

Gypsum applied to the soil surface has often been observed to be more effective than surface applied lime at improving crop yields on soils which have acidic subsoils (Shainberg et al., 1989). The difference in responses to lime and gypsum has generally been related to movement through the soil profile. Gypsum is rapidly leached to the depth of soil where acidity is limiting growth whereas lime movement into the subsoil is generally very slow. A number of mechanisms have been proposed by which gypsum may ameliorate aluminium toxicity in acidic subsoils (Shainberg et al., 1989), although the actual mechanism (s) which operate in different soils remains poorly understood. In some studies, it has been suggested that calcium ( $\mathrm{Ca}$ ) ions displaced Al ions off soil surfaces and therefore cause Al to be leached from the soil in the drainage water (Kotzé and Deist, 1975; Oates and Caldwell, 1985). Other studies however have not reported changes in the concentration of total A.l in the subsoil, and have suggested that an increase in the concentration of $\mathrm{Ca}$ or $\mathrm{SO}_{4}$ ions decreases the toxicity of Al to plants.
In Western Australia, a large area of deep yellow sandplain soils, which occur in a region of low rainfall (c. $300 \mathrm{~mm}^{2}$ nnum ${ }^{-1}$ ), have been shown to have toxic concentrations of $\mathrm{Al}$ which decrease wheat yields (Carr et al., 1991). If leaching of Al from the soil profile was essential for gypsum to effect amelioration, it is uncertain whether there would be sufficient rainlall in the environment where yellow sandplain soils occur for gypsum to be effective. The aim of the experiment. therefore, was to establish wherher leaching of $\mathrm{Al}$ was an essential mechanism for gypsum to decrease $\mathrm{Al}$ toxicity and improve wheat growth in the subsoil of a yellow sandplain soil.

\section{Materials and methods}

A factorial pot experiment was designed with three gypsum rates (0 g gypsum $\mathrm{kg}^{-1}$ - G0;0.142 g gypsum $\mathrm{kg}^{-1}-\mathrm{Gl} ; 0.567 \mathrm{~g}$ gypsum $\mathrm{kg}^{-1}-\mathrm{G} 2$ ) and three leaching regimes (unleached - $\mathrm{L} 0 ; 250 \mathrm{~mm}$ drainage (equivalent to one winter's rainfall) in five daily leaching events of $50 \mathrm{~mm}$ each $-\mathrm{Ll}$; and $500 \mathrm{~mm}$ drainage in five leaching events of $100 \mathrm{~mm}$ each - L2). Soil was incubated overnight at $40^{\circ} \mathrm{C}$ between each leaching 
event. Soil was collected at a depth of $15-40 \mathrm{~cm}$ from a deep yellow sandplain soil in the eastern wheatbelt of Western Australia $\left(117^{\circ} \mathrm{E} ., 32^{\circ} \mathrm{S}\right.$.) which had previously been shown to contain concentrations of $\mathrm{Al}$ in the subsoil solution which decreased wheat yields in the field (Carr et al., 1991). The soil is a sandy clay loam with kaolinite as the major clay mineral. The soil solution had a pH of 3.92 and total $\mathrm{Al}$ concentration of $76.9 \mu \mathrm{M}$. Other properties of the soil have been given by Carr et al. (1991).

The soil was air-dried, sieved $(<2 \mathrm{~mm})$ and weighed $(3 \mathrm{~kg})$ into polythene bags. Gypsum treatments were added to the soil in solid form and thoroughly mixed before adding water to bring the soil to $80 \%$ of field capacity moisture content. All treatments were prepared in triplicate and incubated at $40^{\circ} \mathrm{C}$ for one week to enable reaction of the gypsum with the soil. Soil for the unleached treatment (LO) was then air-dried. Soil for the other leaching treatments was added to $3 \mathrm{~kg}$ pots which had drainage holes at the base and were lined with muslin cloth to prevent soil falling out. Leaching treatments were imposed by adding de-ionised water to the soil surface, at a rate that prevented ponding, until the required amount of daily drainage was collected. Leachate was retained for chemical analysis.

At the completion of leaching, the soil was returned to polythene bags and air-dried. Basal nutrients $(100 \mathrm{~mL})$ were then added to soil in all treatments at the following rates $\left(\mathrm{mg} \mathrm{pot}^{-1}\right)$ : $\mathrm{KH}_{2} \mathrm{PO}_{4}, \quad 1200 ; \quad \mathrm{MgCl}_{2} .6 \mathrm{H}_{2} \mathrm{O}, 200 ; \mathrm{H}_{3} \mathrm{BO}_{3}, 2$; $\mathrm{CuCl}_{2} .2 \mathrm{H}_{2} \mathrm{O}, 10 ; \mathrm{ZnSO}_{4} .2 \mathrm{H}_{2} \mathrm{O}, 15 ; \mathrm{MnSO}_{4} .2 \mathrm{H}_{2} \mathrm{O}$, 10; $\mathrm{Na}_{2} \mathrm{MoO}_{4} .2 \mathrm{H}_{2} \mathrm{O}, 1 ; \mathrm{NH}_{4} \mathrm{NO}_{3}, 160, \mathrm{Na}_{2} \mathrm{SO}_{4}, 30$. $\mathrm{CaCl}_{2} .2 \mathrm{H}_{2} \mathrm{O}, 200$ and $\mathrm{K}_{2} \mathrm{SO}_{4}, 200$ were also added to the control treatment to prevent $\mathrm{Ca}$ or $\mathrm{S}$ deficiency limiting plant growth. After drying, the soils were thoroughly mixed, watered to $80 \%$ of field capacity moisture content, and placed in non-draining $3 \mathrm{~kg}$ plastic pots lined with polythene in a root cooling tank maintained at $18^{\circ} \mathrm{C}$. Fifteen evenly sized seeds of wheat (Triticum aestivum cv. Gutha) were placed in each pot at a depth of $10 \mathrm{~mm}$. The pots were weighed daily and water added to maintain the moisture content. Ten $d$ after sowing, the seedlings were thinned to 10 per pot. Every $10 \mathrm{~d}$, pots received an additional $100 \mathrm{mg}^{-1}$ pot $\mathrm{NH}_{4} \mathrm{NO}_{3}$ to prevent nitrogen deficiency.

The plants in all treatments were harvested after 32 d when it became apparent that the plants grown in pots of the control treatment were suffering $\mathrm{Al}$ toxicity symptoms to an extent that they would not survive much longer. Shoot dry weight (SDW) and root dry weight (RDW) were recorded after oven-drying at 70
${ }^{\circ} \mathrm{C}$. Root length (RL) was measured using a Comair root length scanner (Aerospace Industries Lid.). Soil solution was removed by centrifugation (Gillman and Bell, 1978) and analysed for $\mathrm{pH}$, electrical conductivity $(\mathrm{EC})$, total $\mathrm{Al}\left(\mathrm{Al}_{\mathrm{T}}\right)$ using a colorimetric method (Dougan and Wilson, 1974), cations $\left(\mathrm{Na}^{+}, \mathrm{K}^{+}, \mathrm{Mg}^{2}+\right.$, $\mathrm{Ca}^{2+}$ ) by atomic absorption spectrophotometry and anions $\left(\mathrm{SO}_{4}^{2-}, \mathrm{NO}_{3}^{-}\right.$and $\left.\mathrm{Cl}^{-}\right)$by ion-exchange chromatography. Ionic strength was calculated from EC using the equation of Gillman and Bell (1978). The activities of various aluminium species in the soil solution were estimated using the chemical speciation program TITRATOR (Cabaniss, 1987). The activity of total monomeric aluminium ( $\Sigma \mathrm{Al}_{\text {mono }}$ ) was calculated as the sum of the activities of $\mathrm{Al}^{3+}, \mathrm{Al}(\mathrm{OH})^{2+}$ and $\mathrm{Al}$ $(\mathrm{OH})_{2}^{+}$in the solution.

\section{Results}

Considerable leaching losses of most elements occurred from the soil (Table 1). The total amoun of $\mathrm{H}$ and $\mathrm{Al}$ ions leached increased as both the gypsum application rate and amount of leachate collected increased. The total amount of $\mathrm{Ca}, \mathrm{SO}_{4}$ and $\mathrm{Mg}$ ions leached from the soil also increased $(p<0.001)$ with both the rate of gypsum application and amount of leaching (Table 1), but only small differences in the amount of $\mathrm{K}, \mathrm{Na}, \mathrm{NO}_{3}$ or $\mathrm{Cl}$ ions were generally recorded 'berween either gypsum application rate or leaching regime (data not presented).

Plant growth was affected by both gypsum application rate and leaching regime. In unleached soil, SDW increased with gypsum application rate $(p<0.001)$ and was approximately double the SDW of the control at the highest rate (Fig. 1a). In soil which did not receive gypsum, SDW was approximately $50 \%$ higher $(p<0.001)$ in leached than unleached soil. The highest SDW was recorded for the highest gypsum application rates in leached soil, with no difference $(p<0.05)$ in SDW recorded between the L1 and L2 treatments at the highest gypsum rate. In contrast to shoot growth, no differences $(p<0.05)$ in RDW were recorded between the rates of gypsum application (Fig. Ib), although leaching increased RDW $(p<0.001)$. Root length responses were similar to RDW (data not presented). A poor and non-significant $(p<0.05)$ correlation $\left(r^{2}=0.31\right)$ existed for the relationship between SDW and RDW.

Differences in soil solution chemical properties at the completion of the pot experiment were recorded 
Table 1. Total amount of selected elements leached from soil in pre-leaching, and $\mathrm{pH}$, concentration of total Al and activity of mononeric $\mathrm{Al}$ and $\mathrm{AlSO}_{4}^{+}$(as calculated using chemical speciation program) in soil solution at completion of pot experiment

\begin{tabular}{|c|c|c|c|c|c|c|c|c|c|}
\hline \multirow[b]{2}{*}{ Treatment } & \multicolumn{5}{|l|}{ Leached } & \multicolumn{4}{|c|}{ Soil solution } \\
\hline & $\begin{array}{l}\mathrm{H}^{+} \\
\text {(mmoles) }\end{array}$ & Total Al & $\mathrm{Ca}^{2+}$ & $\mathrm{Mg}^{2+}$ & $\mathrm{SO}_{4}^{2-}$ & $\mathrm{pH}$ & $\begin{array}{l}\text { toral Al } \\
(m M)\end{array}$ & (EAlmono) & $\left(\mathrm{AlSO}_{4}^{+}\right)$ \\
\hline \multicolumn{10}{|l|}{ LO } \\
\hline Go & N.A. & N.A. & N.A. & N.A. & N.A. & 3.77 & 323.3 & 98.5 & 5.6 \\
\hline Gl & N.A. & N.A. & N.A. & N.A. & N.A. & 3.81 & 283.3 & 63.3 & 8.5 \\
\hline $\mathrm{G} 2$ & N.A. & N.A. & N.A. & N.A. & N.A. & 3.81 & 277.5 & 32.2 & 100.4 \\
\hline \multicolumn{10}{|l|}{$L I$} \\
\hline G0 & 0.218 & 0.055 & 0.558 & 0.243 & 0.817 & 3.99 & 171.0 & 74.3 & 20.2 \\
\hline G1 & 0.250 & 0.130 & 1.709 & 0.296 & 2.124 & 3.88 & 144.0 & 48.2 & 31.0 \\
\hline G2 & 0.313 & 0.480 & 5.125 & 0.344 & 6.707 & 3.92 & 171.3 & 50.6 & 43.9 \\
\hline \multicolumn{10}{|l|}{$L 2$} \\
\hline GO & 0.360 & 0.078 & 0.849 & 0.392 & 1.560 & 3.88 & 134.7 & 56.5 & 19.6 \\
\hline G1 & 0.447 & 0.185 & 2.581 & 0.481 & 3.341 & 3.90 & 135.7 & 51.7 & 28.5 \\
\hline $\mathrm{G} 2$ & 0.521 & 0.574 & 7.744 & 0.566 & 10.092 & 3.95 & 97.7 & 34.6 & 24.8 \\
\hline $\operatorname{LSD}_{(0.05)}$ & 0.040 & 0.043 & 0.391 & 0.054 & 0.420 & 0.15 & 68.4 & N.A. & N.A. ${ }^{a}$ \\
\hline
\end{tabular}

N.A. not applicable

a activity estimated from mean concentration of other ions in soil solution, therefore LSD not calculated
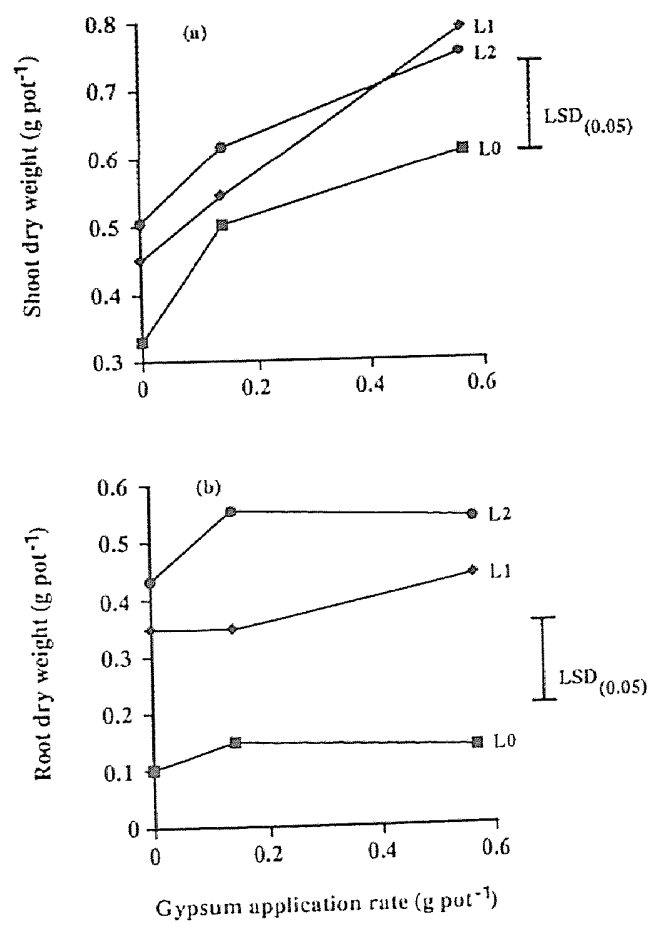

Fig. 1. Wheat shoot (a) and root (b) response to different gypsum application and leaching rates. between both gypsum application rate and leaching regime. Soil $\mathrm{pH}$ was not affected by the rate of gypsum application but was slightly higher in leached soil than unleached soil (Table 1). The concentration of total Al was not affected $(p<0.05)$ by gypsum application rate. However, the amount of $\mathrm{Al}$ as monomeric $\mathrm{Al}$ decreased and the amount as the $\mathrm{AlSO}_{4}^{+}$ion pair increased substantially as the gypsum rate increased (Table 1). The concentration of total Al decreased as the amount of leaching increased and $\mathrm{Al}$ concentrations were less than half of the control soil at the highest leaching rate. The ionic strength, and concentration of $\mathrm{Ca}$ and $\mathrm{SO}_{4}$ ions in the soil solution were all higher as the rate of gypsum application increased, but were lower as the amount of leaching increased. The relationship between ionic strength and total $\mathrm{Al}$ in the soil solution was asymptotic (Eq. 1):

$$
\begin{aligned}
\text { Total } \mathrm{Al}=410.7 & (\log \text { lonic strength) } \\
& +934.2 \mathrm{r}^{2}=0.79
\end{aligned}
$$

$\mathrm{Mg}$ was lower in leached soil than unleached soil, but was not generally affected by gypsum application rate. The concentrations of the monovalent ions measured were also lower $(p<0.05)$ in leached than unleached soil, but unaffected by gypsum application 
rate (data not presented). No significant correlations were recorded between shoot or root dry weight of wheat and the concentration of any ions in the soil solution at the completion of the pot experiment (data not presented). Shoot dry weight (SDW) was best correlated $(p<0.05)$ with the concentration of monomeric Al in the soil solution (Eq. 2):

$$
\begin{aligned}
\mathrm{SDW}= & -0.005 \Sigma\left(\mathrm{A} \mathrm{l}_{\text {mono }}\right) \\
& +0.881 \mathrm{r}^{2}=0.60
\end{aligned}
$$

\section{Discussion}

The increase in wheat shoot growth with higher gypsum application rates in both leached and unleached soil indicated that leaching of Al from the soil is not essential for gypsum to decrease Al toxicity and effect amelioration for wheat. Gypsum therefore could potentially increase wheat yields as long as the dissolution products can reach the $15-25 \mathrm{~cm}$ depth where acidity has been shown to limit wheat growth in the yellow sandplain soils (Carr et al., 1991). The increase in wheat shoot growth in the presence of gypsum coincided with the decrease in monomeric $\mathrm{Al}$ and increase in amount of $\mathrm{AlSO}_{4}^{+}$ion pairs present in the soil solution. These observations support previous suggestions that mechanisms such as an increase in ionic strength (Carr et al., 1991; Ritchie 1989) or formation of $\mathrm{AlSO}_{4}^{+}$ ion pairs (Pavan et al., 1982) can decrease the toxicity of $\mathrm{Al}$ in the soil solution and therefore increase plant growlh.

The Al concentrations recorded in the soil solution of all treatments at the completion of the pot experiment are higher than normally measured in the soil and may be attributed to the higher jonic strength of the soil solution as a result of application of basal nutrients for plant growth. A high ionic strength has previously been shown to increase soluble Al in soils which have large amounts of exchangeable Al (Bruce et al., 1989). However, the asymptotic relationship between total Al and ionic strength suggests that in the presence of gypsum there was either a limit to the amount of Al that could be displaced from exchange sites or an $\mathrm{Al}-\mathrm{SO}_{4}$ compound was procipitating.

Leaching of $\mathrm{Al}$ from the soil was also effective at improving wheat growh since shoot growth as the total amount of leaching increased, both in the presence and absence of gypsum. Amelioration of Al toxicity to wheat by gypsum application is likely to be most effective in soils which have considerable drainage of water through the profile to leach $\mathrm{Al}$ jons which have been displaced off soil colloids beyond the rooting zone.

Rool growth in soils has frequently been reported to be adversely affected by Al toxicity and root bionssays are therefore commonly conducted to predict the effects of Al toxicity on plant growth. In the presence of gypsum, however, we observed that the relative increase in either root weight or root length was considerably less than the relative increase in wheat shoot weight as the rate of gypsum application increased. Therefore, root bioassays may not be suitable for predicting the magnitude of wheat shoot responses 10 gypsum applications on acidic subsoils.

\section{References}

Bruce R C, Bell L C, Edwards D G and Warrell L A 1989 Chemical atributes of some Queensland acid soils. It. Relationships between soil and soil solution phase compositions. Aust. J. Soil Res. 27. 353-364.

Cabaniss S E 1987 TITRATOR: An interactive program for aguatic equilibrium calculations. Env. Technol. 21, 209-210.

Carr S J, Ritchie G S P and Porter W M 1991 A soil test for aluminium toxicity in acidic subsoils of yellow earths in Western Australia. Aust. J. Soil Res. 42, 875-89?.

Dougan W K and Wilson A L 1974 The absorplionerric delermimation of aluminimm in water. A comparison of some chromogenic reagents and the development of an improved metbod. Analys 99. $413-430$.

Gillman G P and Bell L C 1978 Soil solution studies on weathered soils from tropical North Queensland. Aust. J. Soil Res. 16.6777.

Kotzé W A G and Deist 11975 Amelioration of subsurface acidity by leaching of surface applied anendments. A laboratory study Agrochemophysica 7. 39-46.

Oates KM and Caldwell A G 1985 Use of by-product gypsum to alleviate soil acidity. Soil Sci. Soc. Am. J. 49. 915-918.

Pavan M A Bingham F and Prat PF 1982 Toxicity of Al to coffec in ultisols and oxisols amended with $\mathrm{CaCO}_{3} . \mathrm{MgCO}_{3}$ and $\mathrm{CaSO}_{4}$. $2 \mathrm{H}_{2} \mathrm{O}$. Soil Sci. Soc. Am. 1. 46. 1201-1207.

Ritchie G S P 1989 The chemical behaviour of aluminium, hydrogen and manganese in acid soils. In Soil Acidity and Plant Growth Ed. A D Robson. pp 1-49. Academic Press. Sydney. Australia.

Shainberg I, Sumner M E. Miller W P. Farina M W P. Pavan M A and Fey M V 1989 Use of gypsum on soils: A review. Adv. Soil Sci. $91-111$. 